\title{
Exploring English Language Reading Habits of University Foundation Students
}

\author{
Jill Ling Pei Wah*1, Ong Sing Ling ${ }^{2}$ \\ ${ }^{1}$ School of Foundation Studies, \\ ${ }^{2}$ School of Computing and Creative Media, \\ University of Technology Sarawak, \\ No.1, Jalan Universiti, 96000 Sibu, \\ Sarawak, Malaysia. \\ Corresponding author: jill@uts.edu.my
}

\begin{abstract}
Malaysian National Literacy Survey (2005) by the National Library revealed that Malaysians read an average of merely two books a year. Despite various efforts to advocate reading, the number is still low compared to other countries, far from the targeted literacy rate of 100 per cent, one of the aspirations of Vision 2020. This study aims to explore the English language reading habits, interests and attitudes of University of Technology Sarawak (UTS, previously known as UCTS) foundation students. It also determines the reading barriers, motivations and strategies of the students who are immensely impacted by the use of technology in this digital age. The research questions identified the types and sources of reading materials, frequency of items read, their preferred leisure activities, reading activity and enjoyment, anxiety and difficulty, along with strategies utilised to overcome reading barriers. An online questionnaire was filled by randomly selected 230 students (115 male, 115 female), studying in Foundation in Arts and Foundation in Science 2019/2020 session. This study was conducted in a duration of one year and the data collected were analysed descriptively. Results of the study revealed that; (i) the students have poor reading habits with low interest in reading as they prefer other activities to reading; (ii) the students assert their uncertainty towards reading in the English language, indicating poor reading attitudes; and (iii) the students encounter barriers that impede reading with oneself as the most important motivator to improve reading using various strategies. These implied that it is still a long way to foster a healthy reading habit among the younger generation, hence suggestions were given. This study is necessary to provide insights into the current reading habits of the students so that new methods or suggestions can be proposed to foster healthy reading habits, especially among the young, with implications of the findings in terms of academic performance and language learning.
\end{abstract}

Keywords: English, Reading Attitudes, Reading Habits, Technology, University Foundation Students.

\section{Introduction}

Reading, a cognitive process that involves decoding symbols to derive meaning, commences from school age and continues throughout one's lifetime. It is one of the four main language skills other than listening, speaking and writing, closely associated with literacy and academic performance. As technology plays a more encompassing role 
in our lives, parents and educators alike witness a shift in the habits and attitudes towards reading among the young, mostly post-millennials, born 1997 to present (0-21 years old).

The objectives of this research are: To study the reading habits or interests among the foundation students, to determine why students engage in reading and their frequency of reading both hardcopy and online materials respectively, and also to assess how the barriers, motivation and strategies affect their reading habits. This study attempted to answer three research questions:

i) What are the current reading habits and interests of foundation students?

ii) How do their reading attitudes affect reading in the English language?

iii) Which barriers, motivations and strategies affect the development of reading habits?

\section{Literature Review}

\section{Reading and Its Importance}

The definition of reading has evolved with time. Toit (2001) believed that reading is a process of thinking, recalling and relating concepts under the functioning of written words. Braunger and Lewis (2006) defined reading as a process which is active, cognitive and affective. Meanwhile, Noor (2011) claimed that reading is the most important academic language skill for all second and foreign language learners. Reading, as agreed by all, is beneficial in many ways. Scholars and linguists have different viewpoints on reading, but none denies its importance. Reading contributes significantly to job success, career development, and ability to respond to change (Kirsch \& Guthrie, 1984). It not only increases knowledge but also builds maturity and widens awareness of contemporary issues (Kim \& Anderson, 2011).

\section{Reading Habit}

Reading is a conscious activity initiated and oriented by the reader based on different purposes, needs and interests. Shen (2006) identified reading habits as how often, how much, and what the readers read. Green (2001) stressed that reading habit is best formed at a young impressionable age in school, but once formed, it can last one's life time. A good reading habit enables a reader to analyse others' ideas, which makes one think more critically (Cunningham \& Stanovich, 2001). According to Loan (2009), individuals with good reading habits have the chance to widen their mental horizons and multiply their opportunities. Good reading habits act as a strong weapon for the students to excel in life (Bashir \& Mottoo, 2012). Palani (2012) reiterated this by stating that it is an essential and important aspect for creating a literate society in this world. This habit is necessary for healthy intellectual growth and plays a very crucial role in enabling a person to achieve language proficiency (Grabe \& Stoller, 1997).

\section{Reading Attitude}

McKenna, Kear, and Ellsworth (1996) defined reading attitude as a system of feelings related to reading which causes the learner to approach or avoid a reading situation. The degree of positive or negative attitude towards reading differs according to the kind of reading to be performed and the purpose of reading. We read for different reasons, some of which include for pleasure, leisure, relaxation, information and for knowledge. According to Walberg and Tsai (1985), a positive attitude of students towards reading has one of the strongest correlations to reading achievement. 


\section{Reading in Digital Age}

Reading is no longer a hobby but a necessity to keep up with the innovations that science and technology has brought to us. According to Liu (2005), the new reading behaviours are influenced by the availability of digital information and people spend more time reading electronic media. Karim, Hasan, and Shahriza (2007) supported this by claiming that the increasing amount of information and entertainment in a digital format is becoming more popular among the young. A survey conducted by Shen (2006) revealed that English as Foreign Language (EFL) students' reading habits have shifted from paper-based to internet-based reading. The digital formats of the texts enhanced with various features like audio take the readers to the next level which makes reading a fun activity, enabling them to experience more compared to the dull image of conventional paper-based reading. Digital reading takes one to unimaginable places through words. It transfers experiences to the reader to expand his or her horizons, identify, extend and intensify his or her interest, and gain deeper understanding of the world (Green, 2001).

\section{Malaysians' Reading Culture}

Based on Malaysian Literacy Survey conducted in 2005, Malaysians still read an average of two books a year, a progression from two pages a year in 1982. The general trend of reading by students is for examinations rather than for information or pleasure. The World Education Report in 1993 reported that Malaysia has one of the lowest literacy rates $(78.4 \%)$, compared to other Southern Asian countries like Singapore $(100 \%)$, Thailand (93\%), the Philippines $(89.7 \%)$, and Indonesia (81.6\%). So has one of the aspirations of Vision 2020 to become an industrialised nation with a literacy rate of 100 per cent been achieved? Obviously no. Today, with the country's population close to 33 million, our literacy rate is reported at 91.9 percent as recorded by Reading Statistics in Malaysia in 2006, an improved figure from 52 percent when we achieved independence from the British in 1957 which progressed to 80 percent in 1994, but a slight decrease from 93 percent in 1996. It can be seen that the progress has slowed down in recent years. A study by Pandian (1997) on the reading habits of university students in Malaysia revealed that 80.1 percent were reluctant readers of English language materials.

\section{Methodology}

\section{Participants}

This study is a descriptive study in which the sample was procured by means of random sampling. An online survey was used as a method of collecting data. A total of 230 respondents participated in this study. They were students from two foundation programmes: Foundation in Arts and Foundation in Science for 2019/2020 session at University of Technology Sarawak (UTS). Among the participants, 115 students (50\%) are males and the remaining 115 students $(50 \%)$ are females aged 17 to 23 with the majority aged 18 .

\section{Instrument}

A questionnaire was used as the main instrument of this study. In the first part of the questionnaire, demographic information of the respondents was obtained. Their gender, age, hometown, foundation programme, as well as main languages used at home and with friends were acquired. As for the second part of the questionnaire, ten questions were asked: 


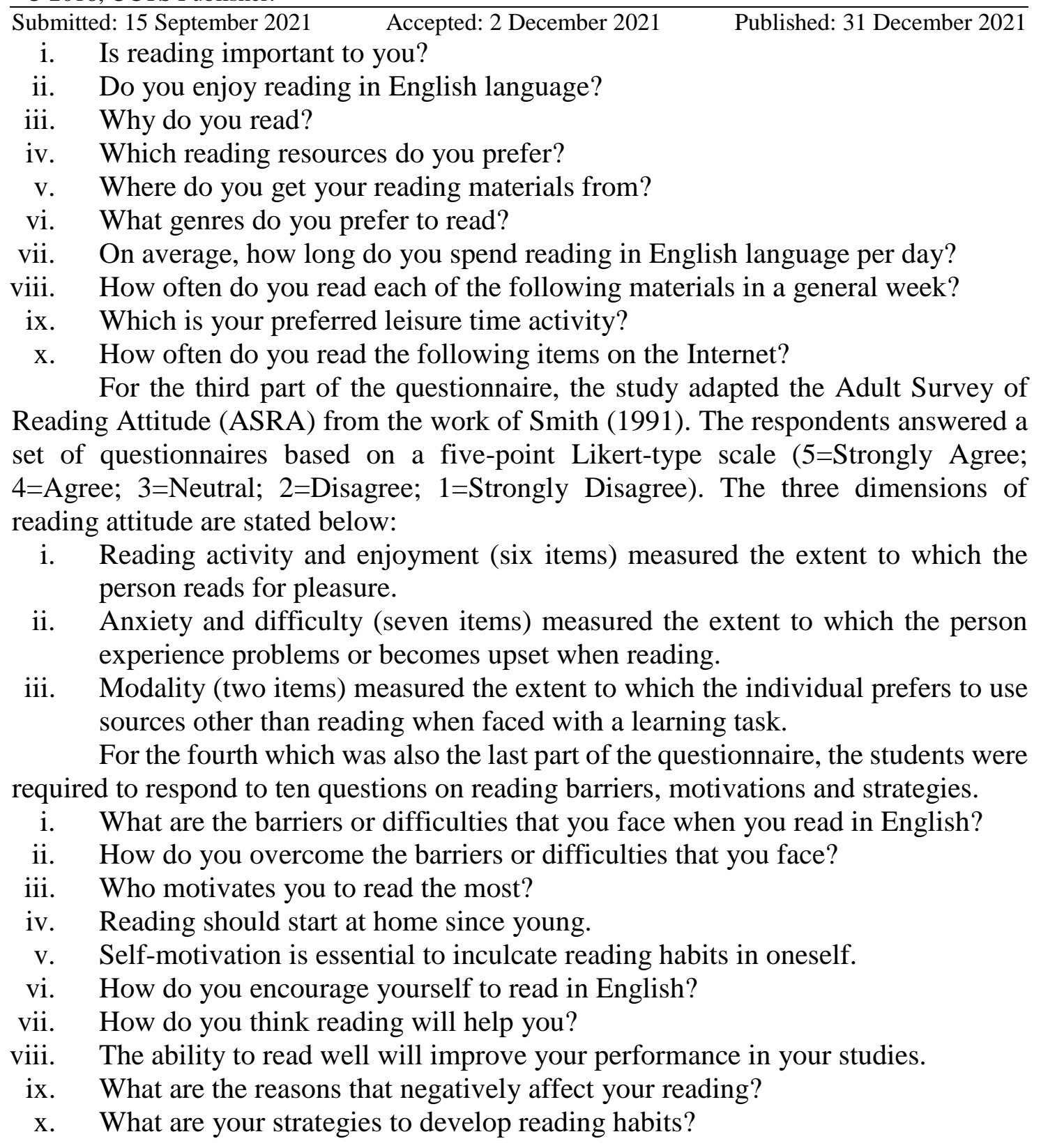

\section{Findings and Discussion}

\section{Demographic}

A total of 230 respondents participated in this study. Among the respondents, 115 of them (50\%) are males and the remaining $115(50 \%)$ are females, aging from 17 to 23 with the majority aged 18.96 percent of the respondents are from Sarawak with almost 50 per cent from Sibu, Sarawak whereas another 4 percent from other states of the country. 67.4 percent of the students were studying in Foundation in Arts and the remaining 32.6 percent in Foundation in Science. Since most of the students are Chinese, presumably the main language used at home and with their friends is Chinese which stands high at 74.8 percent and 67 percent respectively. Approximately, 14.3 percent of the respondents use Bahasa Malaysia at home while 9.1 percent use it with friends. Only 18.7 percent of the students converse in English at home with 20 percent communicate in English with their friends. Less than one fifth of the respondents are active users of the language and therefore, more inclined to read in English. The remaining 7.8 percent 

past who examined learners' reading habits have discovered that reading habits are correlated with gender, age, education background, academic performance, and professional growth.

\title{
Table 1 Profile of Respondents
}

\begin{tabular}{llcc}
\hline & & Number of Respondents & Percentage (\%) \\
\hline Gender & Male & 115 & 50 \\
& Female & 115 & 50 \\
Programme & Arts & 155 & 67.4 \\
& Science & 75 & 32.6 \\
\hline
\end{tabular}

Source: Author

\section{Reading Habits and Interests}

71 percent of the respondents acknowledge that reading is important to them, while 28.3 percent are unsure with 0.7 percent responded 'no'. More than three quarters of the respondents, 76.5 percent, enjoy reading in the English language compared to the remaining 23.5 percent. Generally, the respondents are aware of the benefits that reading brings with only one quarter showing their lack of interest in reading, regarding reading as a trivial activity during their leisure time. Reading is in fact an essential tool for lifelong learning for all learners (Mokatsi, 2005). It can affect one's academic performance and language proficiency (Bashir \& Mottoo, 2012; Grabe \& Stoller, 1997).

1. Is reading important to you? 230 responses

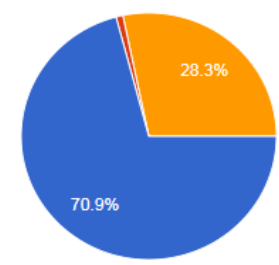

2. Do you enjoy reading in English language? 230 responses

\section{Figure 1: Importance and Enjoyment of Reading}

\author{
Source: Author
}

A majority of the respondents $(69.1 \%)$ read for knowledge or information, half $(50.4 \%)$ read to complement their studies, 45.2 percent read for entertainment or pleasure, 32.2 percent read for personal development, and a minority (30\%) read for leisure or relaxation. They still prefer hardcopy books $(70.9 \%)$ to electronic $(59.1 \%)$. 83.9 percent responded that they get their reading materials from the Internet, 35.7 percent from book stores, 35.2 percent from friends, 24.8 percent from the library, and only 4 percent obtained it from other sources like parents and lecturers. With the existence of reading materials in digital format, reading materials are easily accessible, in short, a convenience for all. Hagood (2003) expounded that educators need to redirect their focus on media and online materials. Most prefer entertainment $(64.3 \%)$ followed by science $(38.7 \%)$, personal development $(35.7 \%)$, psychology $(31.7 \%)$, education $(28.3 \%)$, literature $(22.2 \%)$, history $(17.8 \%)$, religion $(15.7 \%)$, politics $(12.2 \%)$, and others $(7.8 \%)$. On average, 50.9 percent of the participants spend less than an hour reading English material daily, 31.7 percent read one to two hours, 5.2 percent read two to three hours, 2.2 percent three to four, 7.0 percent read more than four hours, with 3.0 

percent never read. The result is low compared to a study conducted by Nor Shahriza and Amelia (2007) whereby students read 7 to 9 hours on average per week.

Table 2 Amount of Time Spent on Reading per Day

\begin{tabular}{lcc}
\hline Hours & Number of Respondents & Percentage $(\%)$ \\
\hline Less than 1 hour & 117 & 50.9 \\
1 to 2 hours & 73 & 31.7 \\
2 to 3 hours & 12 & 5.2 \\
3 to 4 hours & 5 & 2.2 \\
More than 4 hours & 16 & 7.0 \\
Never & 7 & 3.0 \\
\hline
\end{tabular}

Source: Author

When they were asked to rate the materials read in a general week based on a 5point Likert scale, the highest number of students responded that they always read online materials, sometimes read comics and academic books or textbooks, but seldom read magazines, newspaper, journals or articles, and fiction books (stories or novels). Their preferred leisure activities in descending order are as follow: Listening to music $(83.5 \%)$, playing computer or mobile games $(65.7 \%)$, surfing the Internet $(60 \%)$, watching television or movies $(56.1 \%)$, doing outdoor activities $(44.2 \%)$, playing sports or exercising (40.4\%), and studying for exams (20\%). Reading is ranked seventh with 35.1 per cent preferring it. The most read item on the Internet is online news. Sometimes they read emails, comics, movie reviews, advertisements and stories. They seldom read sports, e-books, journal articles, and online magazines.

\section{Table 3 Preferred Leisure Activities}

\begin{tabular}{lcc}
\hline Activities & Number of Respondents & Percentage (\%) \\
\hline Listening to music & 192 & 83.5 \\
Playing computer or mobile games & 151 & 65.7 \\
Surfing the Internet & 138 & 60.0 \\
Watching television or movies & 130 & 56.1 \\
Doing outdoor activities & 102 & 44.2 \\
Playing sports or exercising & 93 & 40.4 \\
Reading & 81 & 35.1 \\
Studying for exams & 46 & 20.0 \\
Others & 17 & 6.9 \\
\hline
\end{tabular}

Source: Author

\section{Reading Attitudes}

The third part of the questionnaire measured the three dimensions of reading attitude; the extent to which the person reads for pleasure. The first six items studied the students' reading activity and enjoyment. From Table 4 , it can be seen that the percentages peak at neutral whereby the students express their uncertainty towards their own reading attitudes, indicating poor reading habits. Overall, less than half of the students like reading $(33.1 \%)$, enjoy reading $(40.9 \%)$, read during their free time $(14.3 \%)$, and want to have more books $(40 \%)$. About half of them enjoy reading when they have time to do so $(50.5 \%)$. On the other hand, 16 per cent of the students dislike reading, 14.8 per cent do not read in their free time, 16.5 percent do not enjoy reading, 37.2 percent do not spend their spare time to read and 31.7 percent do not wish to have more books. Calkins (1996) attributed the best readers to a varied amount of voluntary reading and positive attitudes toward reading. 
Table 4 Reading Activity and Enjoyment (\%)

\begin{tabular}{llccccc}
\hline Item & \multicolumn{1}{c}{ Question } & $\begin{array}{c}\text { Strongly } \\
\text { Disagree } \\
\mathbf{1}\end{array}$ & $\begin{array}{c}\text { Disagree } \\
\text { Reading is one of my }\end{array}$ & $\begin{array}{c}\text { Neutral/ } \\
\text { Uncertain } \\
\text { favourite activities. }\end{array}$ & $\begin{array}{c}\text { Agree } \\
\mathbf{2}\end{array}$ & $\begin{array}{c}\text { Strongly } \\
\text { Agree }\end{array}$ \\
\hline $\mathbf{2}$ & $\begin{array}{l}\text { I read when I have the time } \\
\text { to enjoy it. }\end{array}$ & 3.9 & 13.0 & 50.9 & 25.7 & 7.4 \\
\hline $\mathbf{3}$ & $\begin{array}{l}\text { I get a lot of enjoyment } \\
\text { from reading. }\end{array}$ & 2.6 & 13.9 & 42.6 & 30.9 & 10.0 \\
\hline $\mathbf{4}$ & $\begin{array}{l}\text { I spend a lot of my spare } \\
\text { time reading. }\end{array}$ & 6.5 & 31.8 & 46.5 & 11.3 & 3.9 \\
\hline $\mathbf{5}$ & $\begin{array}{l}\text { When I am at home, I read } \\
\text { a lot. }\end{array}$ & 13.1 & 37.4 & 35.2 & 10.0 & 4.3 \\
\hline $\mathbf{6}$ & $\begin{array}{l}\text { I want to have more books } \\
\text { of my own. }\end{array}$ & 7.8 & 23.9 & 28.3 & 18.3 & 21.7 \\
\hline $\mathbf{S}$ & & & & & \\
\hline
\end{tabular}

Source: Author

Table 5 Anxiety and Difficulty in Reading (\%)

\begin{tabular}{|c|c|c|c|c|c|c|}
\hline Item & Question & $\begin{array}{c}\text { Strongly } \\
\text { Disagree } \\
1 \\
\end{array}$ & $\begin{array}{c}\text { Disagree } \\
2 \\
\end{array}$ & $\begin{array}{c}\text { Neutral/ } \\
\text { Uncertain } \\
\mathbf{3} \\
\end{array}$ & $\begin{array}{c}\text { Agree } \\
4 \\
\end{array}$ & $\begin{array}{c}\text { Strongly } \\
\text { Agree } \\
5 \\
\end{array}$ \\
\hline 7 & $\begin{array}{l}\text { I quickly forget what I have read } \\
\text { even if I have just read it. }\end{array}$ & 12.2 & 23.0 & 31.7 & 23.5 & 9.6 \\
\hline 8 & $\begin{array}{l}\text { I try very hard, but I just cannot } \\
\text { read very well. }\end{array}$ & 20.0 & 28.3 & 31.3 & 13.5 & 6.9 \\
\hline 9 & $\begin{array}{l}\text { I get upset when I think about } \\
\text { having to read. }\end{array}$ & 22.2 & 35.6 & 32.2 & 7.8 & 2.2 \\
\hline 10 & $\begin{array}{l}\text { Encountering unfamiliar words } \\
\text { is the hardest part of reading. }\end{array}$ & 5.2 & 14.4 & 39.6 & 20.4 & 20.4 \\
\hline 11 & $\begin{array}{l}\text { When I read, I usually get tired } \\
\text { and sleepy. }\end{array}$ & 9.1 & 24.8 & 39.1 & 18.3 & 8.7 \\
\hline 12 & $\begin{array}{l}\text { I often feel anxious when I have } \\
\text { a lot of reading to do. }\end{array}$ & 11.3 & 19.6 & 43.0 & 19.1 & 7.0 \\
\hline 13 & I need a lot of help in reading. & 13.9 & 24.8 & 33.9 & 20.0 & 7.4 \\
\hline
\end{tabular}

Source: Author

As shown in Table 5, the subsequent seven items studied the second dimension of reading attitude; the students' anxiety and difficulty faced while reading. A similar trend can be seen whereby the students express their uncertainty for five out of seven items $(31.3-43 \%)$, signifying some inhibition to read. One third $(33.1 \%)$ of the students tend to forget what they have read, one fifth try their best but cannot read well $(20.5 \%)$ and find vocabulary tough $(20.8 \%)$, one tenth $(10 \%)$ get upset if they have to read, and about a quarter feel anxious if they have a lot to read (26.1\%) and need help in reading $(27.4 \%)$. These inhibitions may be the reasons why most students are reluctant readers of English language materials, as claimed by Pandian (1997). 


\begin{tabular}{|c|c|c|c|c|c|c|}
\hline \multicolumn{2}{|c|}{$\begin{array}{l}\text { Submitted: } 15 \text { September } 2021 \\
\text { Table } 6 \text { Modality }\end{array}$} & \multicolumn{2}{|c|}{ Accepted: 2 December 2021} & \multicolumn{3}{|c|}{ Published: 31 December 2021} \\
\hline Item & Question & $\begin{array}{c}\text { Strongly } \\
\text { Disagree } \\
1\end{array}$ & $\begin{array}{c}\text { Disagree } \\
2 \\
\end{array}$ & $\begin{array}{c}\text { Neutral/ } \\
\text { Uncertain } \\
\mathbf{3}\end{array}$ & $\begin{array}{c}\text { Agree } \\
4 \\
4\end{array}$ & $\begin{array}{l}\text { Strongly } \\
\text { Agree } \\
5\end{array}$ \\
\hline 14 & $\begin{array}{l}\text { Reading is one of the best } \\
\text { ways for me to learn things. }\end{array}$ & 1.7 & 4.3 & 31.8 & 34.8 & 27.4 \\
\hline 15 & $\begin{array}{l}\text { There are better ways to learn } \\
\text { new things than by reading a } \\
\text { book. }\end{array}$ & 3.0 & 7.4 & 38.7 & 25.2 & 25.7 \\
\hline
\end{tabular}

Source: Author

The final dimension of reading attitude was measured through two items; the extent to which the individual prefers to use sources other than reading when faced with a learning task. The results indicated that a majority of 62.2 percent agree that reading is a way to learn new things, yet half of them (50.9\%) believe that there are alternative ways to do so, while 38.7 percent are unsure, again a sign of uncertainty. In the survey conducted by Esgin and Karadag (2000) on university youth, it was found that 92 percent of the students do not read adequately while 49 percent of them read most during academic education years. It can be concluded that the reading habit among university students is still lacking with the reason for reading is limited to academic purposes.
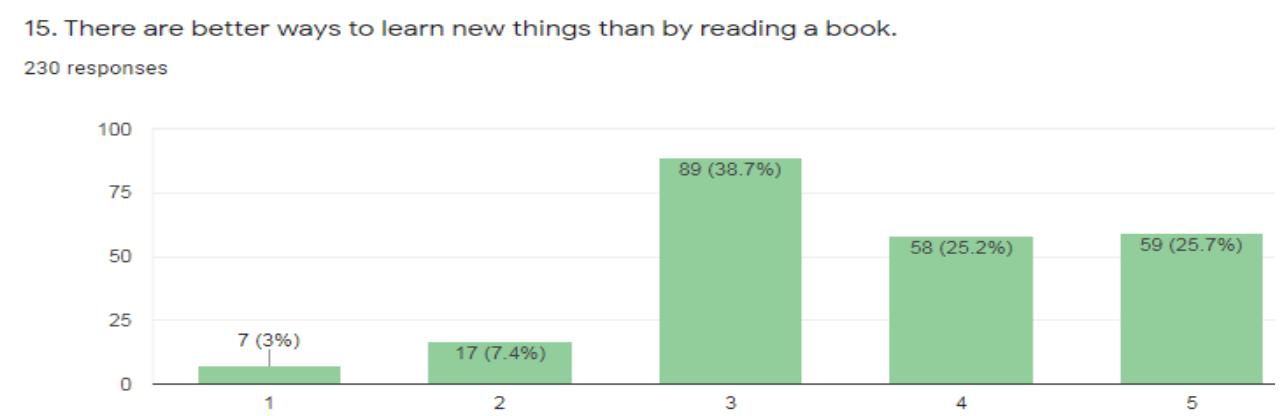

Figure 2: Preference to Use Other Sources than Reading

Source: Author

\section{Analytical Result}

Reliability analysis was run in SPSS before descriptive analysis was done. From the analysis, the Cronbach's alpha value is 0.651 , an acceptable figure based on the previous works done by Pallant (2001), DeVellis (2003), and Nunnally \& Bernstein (1994).

\section{Table 7 Descriptive Statistics of Students' Reading Attitudes}

\begin{tabular}{lll}
\hline Variables & $\boldsymbol{n}$ & Mean \\
\hline Reading activity and enjoyment & 230 & 3.0626 \\
Anxiety and difficulty & 230 & 2.8313 \\
Modality & 230 & 3.7985 \\
\hline
\end{tabular}

Source: Author

The results indicated that the average score for enjoyment (mean value 3.0626) is higher than the average score of anxiety (mean value 2.8313) reflecting that the majority of the respondents stand neutral or are uncertain to agree that reading is an enjoyable activity as majority of them prefer to spend their leisure time on other activities such as listening to music, playing computer games and Internet surfing (Refer to Table 3). However, the low value of anxiety and difficulty towards reading implied 
Submitted: 15 September $2021 \quad$ Accepted: 2 December $2021 \quad$ Published: 31 December 2021 that the respondents still can manage their anxiety and difficulty in reading. The modality variable has the highest mean value of 3.7985 , indicating that the respondents agree with reading as one of the best ways to learn things although there are better ways to learn new things than by reading.

\section{Reading Barriers, Motivations and Strategies}

When asked about the barriers or difficulties faced while reading in English, limitations of vocabulary are recorded as the highest $(51.7 \%)$ with the second barrier being laziness $(47.8 \%)$, and third, occupied with other activities (40\%). Other barriers are time constraint (36.5\%), no interest in reading (29.5\%), and home environment $(25.2 \%)$. Factors related to students' background, home and school have an impact on their reading behaviours (Pandian, 2000). The respondents also claim that their own selves are the most important motivator $(50.4 \%)$, the second being their friends $(15.7 \%)$, teachers come third (13\%), and parents come forth (11.3\%). A majority of 139 out of 230 students $(60.4 \%)$ agree that reading should start at home since young. Almost half $(47.8 \%)$ responded that self-motivation is essential to inculcate reading habits in oneself. A positive reading attitude is significantly related to the following literary environment, such as being read to as a child, having books at home, receiving books as gifts, and possessing a library card (Partin, 2002). Having friends who love to read, with whom they can discuss and recommend books promotes positive reading attitudes too.

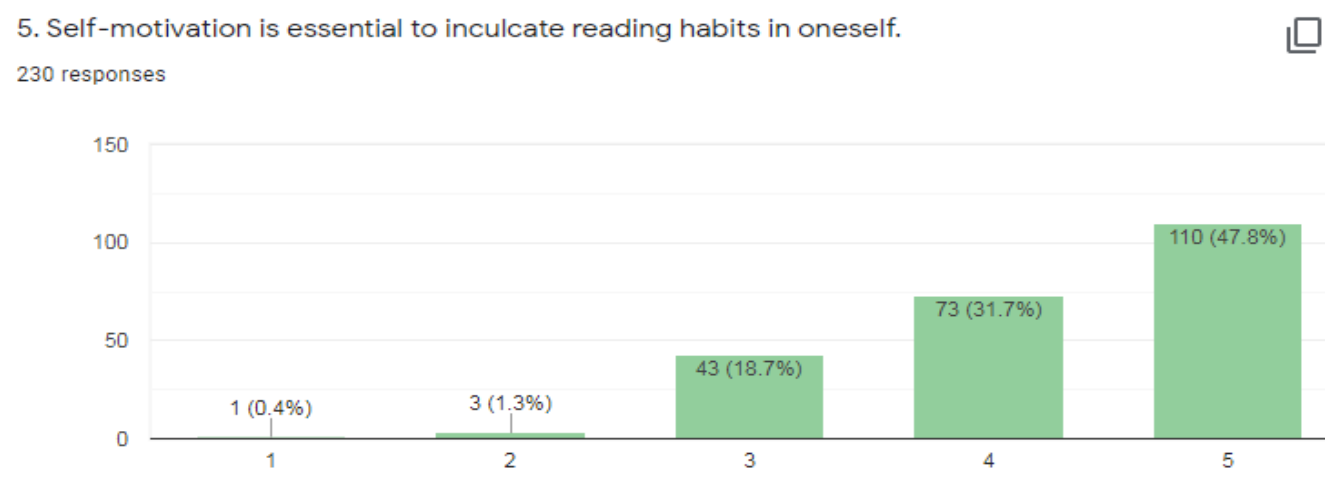

Figure 3: Self-motivation to Read

Source: Author

The respondents are well aware of the significance of reading with 78.7 percent accounting the ability to read to academic performance. Among the strategies that they use to develop reading habits are reading as a means of studying to improve knowledge or skills $(66.5 \%)$, reading materials on hobbies or interests $(57 \%)$, reading more books $(50 \%)$, using dictionary or other reference sources $(44.3 \%)$, motivation by teachers (31.7\%), reading newspapers daily $(26.5 \%)$, and parental guidance and encouragement (23\%). A study by Owusu-Acheaw and Larson (2014) on students of Koforidua Polytechnic, Ghana confirmed that there is a relationship between reading habit and academic performance. This is further supported by Krashen (1993) who stated that through reading, readers develop a good writing style, an adequate vocabulary and advanced grammar and becomes excellent spellers. 


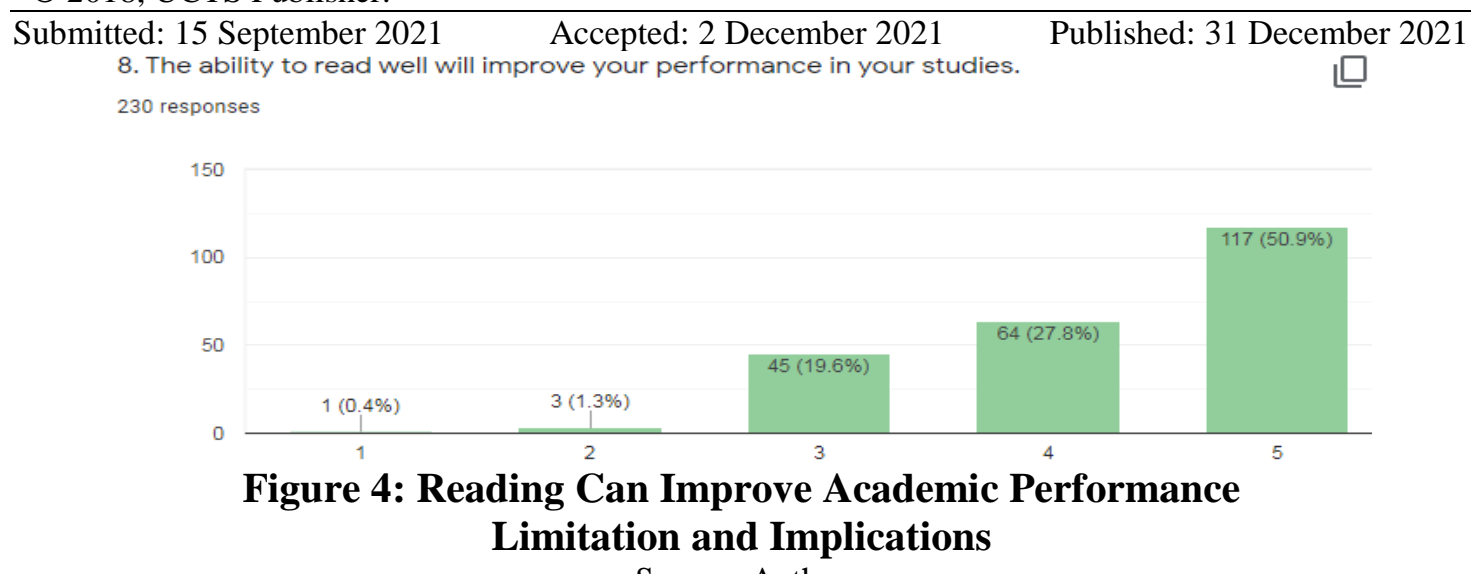

Source: Author

\begin{abstract}
Although the results of this study have presented positive implications on the students' reading habits, this research has several limitations due to small sample size, the inclusion of only one cohort within an institution, and the limited variables, and therefore is not conclusive and may not be able to represent the entire foundation students effectively. This study can be replicated to explore the reading habits of more students of diverse age in different universities across the country, studying more variables such as gender, age, education background, academic performance and professional growth.
\end{abstract}

\title{
Conclusion and Recommendations
}

This study was conducted in an effort to enhance our understanding on the English language reading habits, interests and attitudes of foundation students in a university. In such regard, 230 foundation students from two programmes (Science and Art) were selected randomly as the respondents. The overall results indicated that the students have low interest in reading as they prefer other contemporary leisure activities such as listening to music, playing computer or mobile games, and surfing the Internet to reading, resulting in poor reading habits. Even though three quarters of the respondents know the importance of reading, half of them read for only less than an hour per day. Consequently, reading is only ranked seventh in the list of the most preferred leisure activities. Loan (2009) claims that the new gadgets of technology such as television, smart phone, and Internet have become "time-eating machines", which necessitates action from educators and librarians to encourage the new generation to read. Their uncertainty towards reading in the English language signifies poor reading attitudes with its primary intention for academic purposes only. However, the students acknowledge the difficulties such as vocabulary limitations and mere laziness as barriers that impede reading. Their own selves are the most important motivator to read and hence, they make conscious efforts to implement various strategies to improve reading. Other than that, motivations from friends, teachers and parents are pivotal in instilling a good reading habit, essentially more so if it starts from young.

In this digital era, reading is no longer limited to paper-based resources. With almost everyone owning a computer or smartphone with Internet connection or mobile data, digital reading is much easier to access, cheaper, space-saving and environmentally friendly than the printed or hardcopy books. There are various technological tools to support reading. An e-reader, also known as e-book reader or e-book device, is a mobile electronic device that consists of the hardware and software used to display and interface with digital text. Hardware includes devices, such as e-readers and tablets, as well as 

best e-book readers such as Kindle (Paperwhite and Oasis), Kobo series (Forma, Libra H2O, all-new Kindle Oasis, Clara HD), and NOOK Glowlight Plus (Android) are readily available in the market. Using technology to assist reading is far more superior and entertaining with extra features and special effects. With easy access to e-library and free reading applications or audiobooks like Aldiko, Bookfunnel, Fb Reader, Oodles, Overdrive, and Wattpad, reading is just a tap away. Digital or e-libraries make reading materials readily available. Understanding changes in reading behaviour due to the evolution of electronic documents, would help in designing more sophisticated digital libraries and encourage users to gain benefits from this digital environment (Liu, 2005).

Globally, reading is paid tribute to ever since its first celebration of World Book Day on 23 April in 1995 created by UNESCO to promote the enjoyment of books and reading, encouraging everyone to access books. With Malaysia being named UNESCO World Book Capital in 2020 (KLWBC, 2020), many activities have been organised, including book festival and book lanes with kiosks and murals promoting reading. On 13 February 2020, our former Prime Minister launched the 10-year long National Reading Decade as the government's initiative to promote reading habit among the people, aiming at making Malaysia a reading nation by 2030 . Organised by the Education Ministry, it focuses on increasing the rate of reading and readers, involving people of all levels of society. This reflects the government's conscious effort to create a reading culture and build a society which is knowledgeable, learned and well-informed. We can play our part too through the little things that make the difference. During waiting time at the LRT or bus stop or while queueing up, grab a book and read, or better still, read it online. Parents and schools, too play a role in encouraging reading and sustaining the interest while inculcating the habit of lifelong learning before reading might soon be a long forgotten hobby. Various activities like book club, fun reading programmes, contests or events, reading corner and such can keep it alive.

Undeniably, reading literacy skills are essentially a prerequisite. Hence, reading habits and interests must be developed since young and sustained for lifelong learning. This is because those who read well are believed to have more chances in widening their mental capabilities and better opportunities of success. Overall, reading improves language proficiency. Therefore, it is vital to teach individuals the way to cope with new knowledge by having a good reading habit and attitude in this technologically changing and developing world. A greater motivation to read, by implementing strategies that actually work for them to overcome the barriers that they face, will lead to improvement in their academic performance, and ultimately, a better and more meaningful life.

\section{Acknowledgement}

This study is supported by University of Technology Sarawak (UTS). The authors wish to thank all the students of Foundation in Science and Foundation in Arts of 2019/2020 session at UTS for making this study possible.

\section{References}

Bashir, I. \& Mottoo, N.H. (2012). A study on study habits and academic performance among adolescents (14-19 years old). International Journal of Social Science Tomorrow, 1(5), 1-5. 
Submitted: 15 September $2021 \quad$ Accepted: 2 December $2021 \quad$ Published: 31 December 2021

Braunger, J. \& Lewis, O. (2006). Building a knowledge base in reading: International Reading Association. Edo Journal of Counseling, 2(3), 1-11.

Calkins, L.M. (1996). Lessons from a child. Heinemann.

Cunningham, A.E. \& Stanovich, K.E. (2001). What reading does for the mind? Journal of Direct Instruction, 1(2), 137-149.

DeVellis, R.F. (2003). Scale development: Theory and applications. (2nd Ed.). Sage Publications.

Esgin, A. \& Karadag, O. (2000). The reading habits of the university students. Popular Science, 25(175), 19-20.

Grabe, W. \& Stroller, F. L. (1997). Reading and vocabulary development in a second language: A case study. In Coady, J. \& Huckin, T.N. (Eds.), Second Language Vocabulary Acquisition: A Rationale for Pedagogy, pp. 98-122. Cambridge University Press.

Green, B. (2001). Testing reading comprehension of theoretical discourse with close. Journal of Research in Reading, 23, 267-286.

Hagood, M.C. (2003). New media and online literacies: No age left behind. Reading Research Quarterly, 38(3), 387-391.

Karim, A., Hasan A., \& Shahriza, N. (2007). Reading habits and attitude in the digital age: analysis of gender and academic program differences in Malaysia. The Electronic Library. Retrieved on 6 October 2020. Retrieved from: http://umpir.ump.edu.my/5/1/Reading_habits_and_attitude_at_digital_age__amelia_2.pdf.

Kim, J.Y. \& Anderson, T. (2011). Reading across the curriculum: A framework for improving the reading abilities and habits of college students. Journal of College Literacy and Learning, 37, 29-40.

Kirsch, I.S. \& Guthrie, J.T. (1984). Adult reading practices for work and leisure. Adult Education Quarterly, 34(4), 213-232.

Krashen, S.D. (1993). The power of reading. CO: Libraries Unlimited.

Liu, Z. (2005). Reading behaviour in the digital environment, changes in reading environment over the past ten years. Journal of Documentation, 700-712.

Loan, F.A. (2009). Impact of new technology on reading habits: a glimpse on the world literature. Unpublished manuscript. Retrieved on September 24, 2020. Retrieved from http://eprints.rclis.org/20084/1/NCERT.pdf.

McKenna, M.C., Kear, D.J., \& Ellsworth, R.A. (1996). Children's attitudes toward reading: A national survey. Reading Research Quarterly, 30(4), 934-955.

Mokatsi, R. (2005). Sharing resources - how library networks can help reach education goals. East African Book Development Association. A research paper looking at libraries in the developing world. Commission by Book Aid International.

Noor, N.M. (2011). Reading habits and preferences of EFL post graduates: A case study. Indonesian journal of applied linguistics, 1(1), 1-9.

Nor Shahriza A.K. \& Amelia, H. (2007). Reading habits and attitude in the digital age: Analysis of gender and academic program differences in Malaysia. The Electronic Library, 25(3), 285-298.

Nunnally, J.C. \& Bernstein, I.R. (1994). Psychometric theory (Ed. 3). McGraw-Hill.

Owusu-Acheaw, M. \& Larson, A.G. (2014). Reading habits among students and its effect on academic performance: a study of students of Koforidua Polytechnic. ACADEMIA, 1-22.

Palani, K.K. (2012). Promising reading habits and creating literate social. International Reference Journal, 3(2), 91. 
Pallant, J. (2001). SPSS survival manual: A step by step guide to data analysis using SPSS for Windows (version 10). Buckingham Open University Press.

Pandian, A. (1997). Literacy in postcolonial Malaysia. Journal of Adolescent and Adult Literacy, 440(5), 402-405.

Pandian, A. (2000). A study on readership behaviour among multi-ethnic, multi-lingual Malaysian students. In the $7^{\text {th }}$ International Literacy and Education Research Network (LERN) Conference on Learning, RMIT University, Melbourne, 5-9 July 2000.

Partin, K. (2002). The relationship between positive adolescent attitudes toward reading and home literary environment. Reading Horizon, 43(1), 61-84.

Shen, L. (2006). Computer technology and college students' reading habits. Chia-nan Annual Bulletin, 32, 559-572.

Smith, M.C. (1991). An investigation of the construct validity of the adult survey of reading attitude. In the Annual Meeting of the College Reading Association, Alexandria, Virginia. Retrieved on 23 September 2020. Retrieved from www.cedu.niu.edu/smith/papers/asra.htm.

Toit, C.M. (2001). The recreational reading habits of adolescent readers: A case study. (Unpublished master's thesis). University of Pretoria, South Africa.

Walberg, H.J. \& Tsai, S. (1985). Correlates of reading achievement and attitude: A national assessment study. Journal of Educational Psychology, 78(3), 159-167. 